\title{
DETEKSI DINI DISFUNGSI EREKSI PADA DM MENGGUNAKAN IIEF-5
}

\author{
Hendro Tjoko Tjahjono*
}

STIKes William Booth Surabaya Jl. Cimanuk No. 20 Surabaya

hendrodjokotjahjono@yahoo.co.id

\begin{abstract}
ABSTRAK
Disfungsi Ereksi (DE) merupakan salahsatu bentuk gangguan seksual yang dapat dialami oleh pasien diabetes melitus. Tujuan dari penelitian ini adalah untuk mengidentifikasi secara dini adanya disfungsi ereksi menggunakan instrument International Index of Erectile Function-5 (IIEF-5). Desain yang digunakan dengan pendekatan PICO (Problem, Intervention, Comparison, Outcomes) dan melalui penelusuran jurnal dari Proquest, Ebsco, Science Direct, didapatkan 16 responden. Hasil penerapan menunjukkan disfungsi ereksi ringan dialami 5 orang $(31,25 \%)$, disfungsi ereksi ringan ke sedang 9 orang $(56,25 \%)$ dan disfungsi ereksi sedang 2 orang $(12,5 \%)$. Disfungsi ereksi memerlukan penanganan lebih lanjut untuk meningkatkan kualitas hidup pasien diabetes melitus.
\end{abstract}

Kata kunci : Diabetes melitus, Disfungsi ereksi, IIEF-5

\begin{abstract}
Erectile dysfunction is one form of sexual disorder that diabetic patients can be experienced. The aims of this research is to identify early erectile dysfunction using International Index of Erectile Function-5 (IIEF-5) instruments. The designused with PICO (Problem, Intervention, Comparison, Outcomes) approach and Proquest, Ebsco, Science Direct journal reviews with 16 respondent. The results showed mild erectile dysfunction were 5 person $(31,25 \%)$, mild to moderate erectile dysfunction were $9(56,25 \%)$ and moderate erectile dysfunction were $2(12,5 \%)$. Erectile dysfuntion required further treatment needs to improving diabetic patient quality of life.
\end{abstract}

Keywords : Diabetic patient, Erectile dysfunction, IIEF-5 


\section{Pendahuluan}

Disfungsi ereksi (DE) adalah ketidakmampuan yang persisten dalam mencapai atau mempertahankan fungsi ereksi secara memadai selama melakukan aktivitas seksual atau berhubungan intim. Pengertian tersebut menunjukkan bahwa proses fungsi seksual lakilaki mempunyai dua komponen yaitu mencapai keadaan ereksi dan mempertahankannya (ADA, 2017). Faktor organik, kondisi psikis dan hormonal (andropause) berkaitan dengan terjadinya DE.Pada laki-laki yang berumur lebih dari 40 tahun akan mengalami penurunan kadar testosteron dalam darah secara bertahap sekitar $1,2 \%$ per tahun dan mencapai $70 \%$ pada usia 70 tahun (Feldman et al, 2004).

Menurut Bilous (2014), dan Rudijanto et al, (2015), prevalensi DE pada pasien diabetes melitus berkisar antara 35\%-90\%. Kondisi tersebut dapat diakibatkan karena neuropati otonom, angiopati dan problem psikis. Laporan National Institutes of Health, NIH (2002), menunjukkan kurang lebih 15 juta sampai 30 juta laki-laki di Amerika mengalami disfungsi ereksi. Insiden terjadinya gangguan tersebut bervariasi dan meningkat seiring dengan usia. Pada usia 40 tahun, terdapat kurang lebih 5\% laki-laki mengalami keadaan disfungsi ereksi, sedangkan pada usia 65 tahun angka kejadiannya meningkat 15-25\%. Menurut National Diabetes Information Clearinghouse (NIDDK) (2008), gejala perubahan fungsi seksual adalah masalah yang umum terjadi seiring bertambahnya usia, apalagi kondisi tersebut disertai oleh adanya diabetes mellitus. Prevalensi DE pada pasien diabetes bervariasi antara $20-75 \%$, laki-laki yang menderita diabetes 2-3 kali lebih banyak cenderung mengalami disfungsi seksual dibandingkan laki-laki yang tidak menderita diabetes. Onset terjadinya DE pada pasien diabetes dialami 10-15 tahun lebih awal dibandingkan laki-laki tanpa diabetes.

Pasien diabetes melitus (DM) yang mengalami DE perlu mempertimbangkan untuk berdiskusi dengan petugas pemberi layanan kesehatan. Perawat kemungkinan akan menanyakan hal-hal yang berkaitan dengan faktor resiko dan penyebab terjadinya DE seperti riwayat kesehatan masa lalu, masalah seksual, penggunaan obat-obatan, kebiasaan merokok dan riwayat minum alkohol. Selanjutnya pasien diabetes akan dilakukan pemeriksaan fisik dan pemeriksaaan laboratorium seperti kendali glukosa darah atau kadar hormon dalam darah untuk membantu menentukan penyebab DE (NIDDK, 2008). Deteksi dini DE pada pasien diabetes melitus tipe-2 sangat penting dilakukan sebagai upaya pencegahan terhadap komplikasi kronis dan untuk meningkatan kualitas hidup pasien. Deteksi dini ini bertujuan agar pasien dapat memperoleh tindakan selanjutnya. Oleh karena itu, diperlukan suatu instrument pengkajian yang dapat mengidentifikasi adanya disfungsi ereksi pada pasien diabetes melitus tipe-2. Instrument yang dapat digunakan untuk mengidentifikasi DE pada pasien diabetes melitus tipe-2 adalah International Index of Erectile Function-5 (IIEF-5). Instrument IIEF-5 ini dikembangkan oleh Capelleri et al (1999) dan Rosen et al (2002).

Berdasarkan fenomena yang diamati oleh penulis, pasien diabetes melitus jarang mengungkapkan masalah DE kepada petugas kesehatan dan juga belum adanya instrument khusus yang digunakan oleh perawat untuk mengidentifikasi masalah DE pada pasien diabetes melitus tipe- 2 .

\section{Metode}

Metode yang digunakan adalah dengan pendekatan PICO (Problem, Intervention, Comparison, Outcome). Problem yakni masalah disfungsi ereksi pada pasien diabetes melitus tipe-2 yang jarang diidentifikasi dan diungkapkan, Intervention menggunakan instrument International Index of Erectile Function-5 (IIEF-5), Comparison adalah format pengkajian awal pasien dan Outcomes nya masalah DE pada pasien diabetes melitus tipe-2 dapat diidentifikasi dan direncanakan intervensi selanjutnya.

Dalam penerapan instrument IIEF-5 ini diperlukan jurnal-jurnal pendukung. Berdasarkan penelusuran dan telaah jurnal melalui databased Proquest, Science Direct, Ebsco, Sage dan Spinger Link dengan kata kunci yang digunakan yaitu"erectile dysfunction", "diabetic tools", ditemukan beberapa artikel maupun jurnal yang terkait antara lain "Prevalence of erectile dysfunction among 7689 patient with diabetes or hypertension or both" (Giuliano et al,2004), "Prevalence and risk factors for erectile dysfunction in 2869 Men using a validated questionaires" (Anton Ponholser, et al 2005), dan Erectile dysfunction in diabetes mellitus (Mota et al, 2003).

Kriteria inklusi yang digunakan yaitu pasien diabetes melitus yang berusia $\geq 40$ tahun, bersedia ikut berpartisipasi dan pasien mampu membaca dan menulis, sedangkan kriteria eksklusinya adalah pasien yang tidak melengkapi seluruh item pertanyaan yang tercantum dalam instrument IIEF-5 dan pasien diabetes melitus tipe-2 yang tidak aktif melakukan hubungan seksual. Pengambilan data dilakukan selama 2 minggu dimulai pada April - Mei 2018 di poliklinik metabolik endokrin RSUPN Cipto 
Mangunkusumo dan diperoleh responden sebanyak 16 orang.

\section{Hasil}

Data responden yang disajikan khusus tentang disfungsi ereksi. Adapun distribusinya adalah sebagai berikut :

Tabel 1 Distribusi derajad DE responden DM di poliklinik metabolik endokrin RSUPN Cipto Mangunkusumo $(\mathrm{n}=16)$

\begin{tabular}{lcc}
\hline $\begin{array}{l}\text { Katagori } \\
\text { IIEF-5 }\end{array}$ & Frekwensi & Prosentase \\
\hline Ringan & 5 & $31,25 \%$ \\
\hline $\begin{array}{l}\text { Ringan ke } \\
\text { sedang }\end{array}$ & 9 & $56,25 \%$ \\
\hline Sedang & 2 & $12,5 \%$ \\
Berat & 0 & $0 \%$ \\
\hline & 16 & 100 \\
\hline
\end{tabular}

\section{Pembahasan}

Berdasarkan tabel diatas, derajad DE yang terbanyak dialami responden adalah derajad ringan ke sedang yaitu 9 orang $(56,25 \%)$. Hasil ini tidak sejalan dengan beberapa penelitian yang dilakukan oleh Rosen (2002) dan Anton et al (2005), dimana kejadian DE yang terbanyak dialami oleh responden DM adalah derajad ringan. Meskipun begitu, menurut Giuliano et al (2004), kondisi kesehatan seperti DM, hipertensi, hiperdislipidemia, faktor psikologis menunjukkan signifikansi terhadap prevalensi DE dengan berbagai derajad keparahan DE.

Hambatan yang ditemukan selama pelaksanaan yaitu terdapat beberapa responden yang mengalami kesulitan untuk mengisi dan melengkapi instrument IIEF-5 karena mengalami retinopati sehingga harus dibantu dalam mengisi instrument IIEF-5. Hambatan lain yang ditemukan adalah belum tersedianya ruangan khusus dipoliklinik yang digunakan untuk mengisi kuesioner IIEF-5.

\section{Kesimpulan}

Kesimpulan dalam kegiatan ini adalah instrument IIEF-5 dapat digunakan untuk mendeteksi DE pada pasien DM, pasien merasa senang dan merasakan manfaatnya. Untuk saran yang dapat dilakukan adalah perlu nya modifikasi instrument IIEF-5 dari bentuk tertulis menjadi bentuk audio sehingga instrument dapat digunakan oleh pasien yang mengalami retinopati.

\section{Referensi}

ADA, (2017), The Journal of Clinical and Applied Research and Education, Januari, Vol.40, Supplemen 1, Diabetes Care: Standards of Medical Care in Diabetes
Aini, N \& Aridiana, L.M., (2016) Asuhan Keperawatan pada Sistem Endokrin, dengan pendekatan NANDA NIC NOC, Salemba Medika, Jakarta

Anton P., et al (2005). Prevalence and risk factors for erectile dysfunction in 2869 Men using a validated questionaires, European Urology 47: 80-86

Bilous, R \& Donelly, R (2014). Buku Pegangan Diabetes, Edisi 4, Jakarta: Bumi Medika.

Cappeleri J, et al (1999), Diagnostic evaluation or the erectile function domain of the international index of erectile function, Urology 54:346-351

Feldman HA, Goldstein I, Hatzichrictou DG,Krane RJ, McKinley JB. (2004), Impotence and itsmedical and psychosocial correlates : results ofthe Massachusetts Male Aging Study. J Urol ; 151:54-61

Giuliano F.A., Lerichie A, Jaudinot E, Gnedre A.S (2004), Prevalence of erectile dysfunction among 7689 patient with diabetes or hypertension or both, Adult Urology 64 (6) :1196-1201, Elsevier Inc.

Mota et al (2003), Erectile dysfunction in diabetes mellitus, Romanian journal of internal medicine. www.researchgate.net/publications/819331 43; vol 41:2

National Diabetes Information Clearinghouse (NIDDK), (2008). Sexual and Urologic problem of Diabetes, NIH Publication No.09-5135.

Rosen, C et al (2002). The use of the Simplified International Index of Erectile Function (IIEF-5) as a diagnostic tool to study the prevalence of erectile dysfunction International Journal of Impotence research 11:319-326

Rudijanto et al (2015). Konsensus Pengelolaan dan Pencegahan Diabetes Melitus Tipe 2 Di Indonesia, PB Perkeni 